\title{
THE ARAB AWAKENING AND ITS POLITICAL ECONOMY
}

\author{
by Marek Rewizorski
}

\section{INTRODUCTION}

The Arab world extending from Tunisia to Egypt, reaching Jordan, Lebanon, the Yemen Republic and Sudan, in autumn 2010 was plunged into a state of turbulent unrest. Tunisia provided the incendiary spark which set fire the Arab worlds long politically suppressed by authoritarian regimes and monarchial kingdoms. The unrest started in Tunisia where successful mass protests ignited in December 2010, in a bid to overthrow the president after being in power for 23 years. The region came further into focus as another North African country - Egypt - sparked off similar protests, leading to overthrowing President Mubarak, who had reigned for 30 years. The protests spread to Algeria, Bahrain and Yemen Republic. Libya also became a field of prolonged revolts, and there has also been a revival of the protests in Iran.

Many commentators suggest that the Middle East political turbulence was foreseeable and it cannot be said it had been unexpected. However, the diplomatic and intelligence establishments in the United States and the European Union, which have the most crucial stakes in this region, seemed to have been so preoccupied with focusing on Al Qaeda, Hezbol- 
lah, Hammas, and the Taliban that in a narrow picture they seem to have lost sight of the revolutionary wave, which has altered the governments in Tunis and Cairo and shaved off some of the most hated and oppressive regimes with the sheer example of Hosni Mubarak and Muammar Qaddafi. The spectacular fall of such dictators as Mubarak, has led to the question, whether the "Arab Awakening" was a transformation or a revolution. There are also questions concerning the idea of democratisation of the third world and corruption, which change the Arab governments into "bad apples". According to the western view, democracy is a Janus-faced ideological god, pulling the strings of both politics and economics. One cannot exist without the other, therefore, when we reconsider the political aspect of the Arab uprising, we should not forget about the economy.

In this article I argue that a democratic transition, though important, is only one of the divergent ways of explaining an Arabian "wind of change". Undoubtedly, there is a democracy and freedom "deficit" in the Arab world and one may ask the question why the Arab world has experienced such a deficit. However, in an attempt to understand the complex causes of a wave of unrest across the Arab world, people sometimes ask whether the real drivers were economic rather than political. Having some insight into the potential role of economics in the uprising one may suggest that protesters hid themselves behind a "curtain of democracy" while in fact they were screaming against unbearable living standards, deteriorating food security, child malnutrition, youth unemployment, corruption and overall poverty, which rise despite GDP growth. The economies of the Arab world are fundamentally shaped by the region's political, social and institutional structures, and economic problems such as unemployment, inflation and inequality, which are inextricably bound up with the political context. Yet, I tend to argue that the Arab Spring is really about jobs, bread and housing rather than democracy, which is second in line. 


\section{EXOGENOUS FACTORS INFLUENCING THE ARAB AWAKENING AND UNEMPLOYMENT}

In September 2011 Andrew Mitchell, the UK Secretary of State for International Development, commenting on the Arab Spring noticed: "When the momentum of revolution fades, those who seek lasting change have to deal in the currency of processes, procedures and systems"1. Amongst the varied challenges he enlisted: economic stability, obtaining the trust of people by new governments, bringing back strong belief in the potential of business, and lastly a crying need for more jobs - especially for young people - across the Southern Mediterranean countries. In practice, all these challenges had a lot to do with economics. The most important - economic stability across North Africa and the Middle East in the concept of A. Mitchell - has been set as a chance to resign from the state-controlled economic systems of the region, which failed to work out for ordinary people, and the possibility to introduce stabilizers of the postrevolt situation, preventing against replicating the chaos that befell countries like Russia in the aftermath of the Cold War².

Indeed, the economy may be considered therefore as a key element both to disrupt and to restore stability in Arab countries. Since the eruption of the "oil crisis", the world is carefully tracing developments in the resource policy of the Arab states. However, their engagement in economic globalization undergoes structural impediments, which may be considered as a significant cause of the Arab Awakening, as there has been a basic tension between the stated objectives of Middle Eastern leaders to integrate their countries into the world economy on the one hand, and the actual tangible levels of this integration on the other. Non-democratic states of the Middle East and North Africa have long and consistently lagged behind in such globalization indicators as foreign direct investment (FDI), competiveness, market growth and integration into international markets. Exogenous and indigenous factors responsible for the limited nature of

1 A. Mitchell, The Economics of the Arab Spring, conference speech - transcript, "Chatham House", 12.09.2011.

2 Ibidem, p. 5. 
globalization in the Middle East, as authoritarian practices and political structures in the region, significantly undermined prospects for economic development and the prosperity of Arab societies. Many studies of globalization in the Middle East have linked the region's comparatively low levels of global economic integration to a combination of insufficiently developed local markets, an underdeveloped or non-existent labour force, inadequate and inaccessible information technologies and the panicky reaction of political leaders as Qaddafi to socio-political changes of globalization ${ }^{3}$.

The Arab world is very diversified in terms of economic performance. The World Bank for example uses a criterion of gross national income (GNI) per capita to classify a country to a specific group (low income, middle income - subdivided into lower middle and upper middle, or high income $)^{4}$. The gross national income varies in range in Arab countries significantly. The developing economy of Egypt is ranked $148^{\text {th }}$ worldwide with GNP per capita of approx $\$ 2,410$. It is similar to the international position of other Arab countries such as Syria $\left(\$ 2,410\right.$, ranked $\left.144^{\text {th }}\right)$, or Tunisia $\left(\$ 3,740 \text {, ranked } 124^{\text {th }}\right)^{5}$. However, some of them, like Bahrain or the United Arab Emirates are classified amongst high income economies. Calculation based on income is important to tell us more about the "terms and conditions" of Arab countries' participation in globalization. A striking fact is that in terms of income, the population of the Middle East and North Africa in the early 1990s had per capita annual income little more than a tenth of the European Community: $\$ 2,124$ against $\$ 20,738$. If Israel and the oil-rich Gulf Cooperation Council (GCC) countries were factored

3 See C.M. Henry, R. Springborg, Globalization and the Politics of Development of the Middle East, Cambridge 2001.

4 Low and middle income economies are sometimes referred to as developing economies. Low income economies are those with a GNI per capita of 995 or less in 2009. Middle income economies are those with GNI per capita of more than $\$ 995$ but less than $\$ 12,195$. Lower middle income and upper middle income economies are separated at a GNI per capita of 3,945. High income economies are those with GNI per capita of 12,196 or more. See World Development Indicators 2011, "The World Bank" 2011, p. xxiii.

5 Ibidem, pp. 10-12. 
out of the equation, the former figure fell to $\$ 1,489^{6}$. On index after index, the region was not just behind but falling further behind not only Europe, but also significant parts of the developing world7. The Middle East is also seriously underachieving in international economic performance. The region's ability to attract foreign direct investment (FDI) is not satisfactory, compared to the great potential, negatively influenced by political turbulences. As a good example, the Arab world and Iran were almost entirely outside of the flow of capital for developing countries that marked the

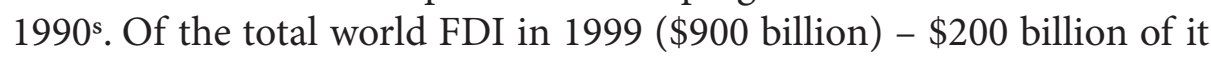
went to developing countries, but the Middle East and North Africa, excluding Israel, attracted only around only $\$ 10$ billion ${ }^{8}$.

According to Fred Halliday, the international political economy of Arab countries emerged as a result of the oil boom of the $1970^{\text {s, }}$, when substantial flows of money and labour crossed regional frontiers ${ }^{9}$. However, oilproducing states in the $1970^{\mathrm{s}}$ and $1980^{\mathrm{s}}$ wasted money for political purposes often arbitrary, military purchases, and subsidies to friendly states and client movements. Furthermore, agricultural self-sufficiency in the region was down and great changes were limited by the restrictions on water. Economic development of the Arab world was interconnected to the output of oil. Between 1960 and 1984 average dynamics of the economic growth reached a level of $2.5 \%$ (higher value $-4.3 \%$ reached only countries of the Asia-Pacific region). Relatively high economic growth was geared on the dynamic of social development and resulted in a fivetimes increase of GNP per capita to $5300 \mathrm{USD}^{10}$. In the second half of the $1970^{s}$ economic growth in the Arab world was even more significant (8.6\%) however, with the dramatic fall of oil prices this spectacular eco-

6 J. Roberts, Visions and Mirages: the Middle East in a New Era, Edinburgh 1995, p. 24.

7 Arab Human Development Report 2002, Geneva and New York: UNDP, 2002, http://www.undp.org/rbas/ahdr [10.01.2012].

8 UNCTAD, World Investment Report 2000.

9 F. Halliday, The Middle East in International Relations Power, Politics and Ideology, Cambridge 2005, p. 265.

10 I. Elbadawi, Reviving Growth in the Arab World, "Economic Development and Cultural Change", January 2005, pp. 293-294. 
nomic expansion of the Arab economy has ceased ${ }^{11}$. The decade of the $1980^{\text {s }}$ was signalled by the breakneck fall of GNP in Arab countries, redirected slowly with restoring the oil supply in 2003. It is worth noting that in the $1980^{\text {s }}$ the GNP per capita of Arab countries surpassed only those of Sub-Saharan Africa (see table 1).

Table 1. Economic growth in the Arab World, 1960-2000 (in \%)

\begin{tabular}{|l|c|c|c|}
\hline Type of economy/region & $1960-1984$ & $1985-1994$ & $1995-2000$ \\
\hline Mixed/based on oil output & 1.9 & -2.1 & 1.6 \\
\hline Based on oil output & 5.5 & 1.6 & 0.8 \\
\hline Economically diversified & 3.1 & 1.4 & 0.8 \\
\hline Based on export of raw material & 0.4 & -1.3 & 1.2 \\
\hline The Arab World & 2.5 & 1.1 & 1.2 \\
\hline Eastern Asia & 4.3 & 5.2 & 2.9 \\
\hline Sub-Saharan Africa & 1.1 & -1.1 & 0.3 \\
\hline
\end{tabular}

Source: I. Elbadawi, Reviving Growth in the Arab World, "Economic Development and Cultural Change", January 2005, pp. 293-294

As we may observe, the economic growth in Arab countries in the $1980^{\mathrm{s}}$ and $1990^{\text {s }}$ was increasing at a lower rate than in other developing econo-

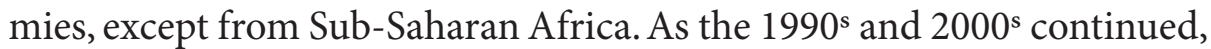
insufficient productivity and external competitiveness was therefore matched and compounded by growing internal, regional, socio-economic crisis. Within Arab countries factors of an economic and social kind exerted a growing pressure on relationships within states. Demographic rise, pressure on employment, urbanisation all contributed to creating political tension, a shifting in state policy and gradual strengthening of contestatory movements of a mainly religious orientation with, nonetheless, material issues like employment or trade rules underpinning them. The most pressing question facing states in the region was that of how to

11 As "the Arab world" I consider states annually reviewed by UNDP in Arab Human Development Reports, such as: Algeria, Saudi Arabia, Bahrain, Egypt, Iraq, Yemen, Jordan, Qatar, Kuwait, Lebanon, Libya, Mauritania, Morocco, Oman, Sudan, Syria, Tunisia, The United Arab Emirates. 
manage the pressures from below directed at employment and distribution of wealth. Unemployment posed, and still does a major source of economic insecurity in most Arab countries. The question of "how to tackle it" is still relevant because Arab states as a region are distinguished today by having the highest unemployment rate in the world, conservatively estimated at $16 \%$ of the labour force. In 2005 it was estimated by the Arab Labor Organization at $14.4 \%$, compared to $6.3 \%$ for the world at large. As unemployment rates were declining in most regions of the world over the last three decades, they increased in most Arab states, particularly in the poorer ones Algeria, Egypt, Iraq, Jordan, Morocco, Sudan, Syria, Tunisia and Yemen, which represent together over $85 \%$ of the Arab population. Today, while unemployment is as low as $2 \%$ in Qatar, it is as high as $22 \%$ in Mauritania ${ }^{12}$. The rich oil-exporting states, with the exception of Saudi Arabia, have an average unemployment rate of $4 \%$; the Saudi Arabia rate is about $8 \%$. However, low unemployment rates in rich Arab states do not reflect strong economic performance: they rather reflect high oil revenues that enables the state to employ more nationals and import more foreign workers to serve them.

The current global economic crisis is expected to increase the numbers of the unemployed by 5-6 million people, and people living in poverty by 8-10 million. Unemployment in the Arab countries not only affects youth, but it also wears "a female face". What is interesting, unemployment rates for young Arab women are higher than those for young Arab men and are among the highest in the world. According to data collected by the Arab League Organization (ALO) in 2005 the average unemployment rate for men in Arab countries showed that female unemployment varied from 59 per cent in Jordan (compared to 35 per cent for men) to 5.7 per cent in UAE. A glimpse of hope comes from Bahrain, Mauretania and Yemen, where, according to the ALO, the unemployment rate for women is lower than for the young men ${ }^{13}$. Discrimination of women in the labour market concentrates mostly in their increasing participation in the production of

12 Arab Human Development Report 2009, Challenges to human security in the Arab Countries, UNDP, New York 2009, p. 108.

13 The rate of unemployed women in Bahrain in 2005 reached 18\% compared to 28 per cent of males. Similar situation has occurred in Mauretania (41 per cent compared 
agricultural goods, characterized as a low-wage system of semi-slavery work, in many cases especially stripping young women of social insurance or benefits.

There is an explicit relationship between unemployment, poverty and the social unrest in North Africa and the Middle East. One of the triggers for the wave of protests that swept through Tunisia in December 2010 and January 2011, was sparked off by the tragic suicide of Mohammed Bouazzi, a young man working informally as a vegetable seller after his unlicensed vegetable cart was confiscated by the police. The Arab street, full of desperate individuals, who fell under the same very difficult conditions, shared Bouazzi's experience of unemployment, but also found the possibility to express their frustration and dissatisfaction with a corrupt system, that was seen as a "law enforcement facility" against the poorest and for the increasingly flagrant theft of land and resources by the elite ${ }^{14}$. Indeed, this dramatic incident has shown a profound economic problem of the Arab countries where citizens seize on any means of making a living when they cannot find permanent jobs. Inhabitants of the West, "shiny, happy people" should not forget that the definitions of unemployment that fit the developed world are of limited relevance to the Arab states, where a few hours' work a week is sufficient to have someone taken off the unemployment register. Bouazzi's suicide which sparked the Arab uprising has shown a huge and still expanding informal sector where workers lack contracts and benefits. UNDP figures show that Algeria, Egypt, Morocco and Tunisia have very large informal sectors comprising between 40 and 50 per cent of non-agricultural employment. Compared to men, the rate for women is lower in Syria, Algeria, and Tunisia and higher in Egypt and Morocco $^{15}$. In the view of many international agendas there are three primary factors responsible for slumping employment trends in Arab

to 49 per cent) and Yemen, where two sexes fare equally (14 per cent for both), See Arab Human Development Report 2009, p. 110.

14 J. Kinninmont, Bread and Dignity, “The World Today”, Chatham House, August-September 2011, p. 32.

15 Human Development Report 2006. Beyond scarcity: power, poverty and the global water crisis, New York 2007, Human Development Report 2007/2008. Fighting Climate Change: Human Solidarity in a Divided World, New York 2008. 
countries ${ }^{16}$ : the contraction under structural reforms of the large public sector which employs more than a third of the workforce, the limited size, hobbled performance and weak job-generating capacity of the private sector, the quality and type of generally provided education which does not stress technical or vocational skills in demand.

\section{INDIGENOUS FACTORS INFLUENCING THE ARAB AWAKENING}

Many scholars indicate a list of indigenous economic factors influencing sparking off the Arab uprising. According to an interesting view by Mehran Kamrava, among the most important factors negatively influencing the prosperity in Arab countries, which have pushed protesters to despair, are: the "ruling bargains" that underlined authoritarian systems, state trade policies, etatism and the development of a "semiformal" sector in Middle Eastern economies ${ }^{17}$.

The first of the features - authoritarian ruling bargains keeps Arab economies out of greater integration into the global economy because the state provides for the needs of social classes being politically relevant, in return for their acceptance of the lack of political accountability and representation. This state of play in internal policy brings about the eruption of etatism and economic nationalism which undermines the economic and political chances a country can gain from globalization. The economic policy in the Middle East and North African (MENA) countries is defined by corporatism, clientelism, and rentierism. Many oil monarchies are in fact strongly dependent on the ruling clans of wealthy merchants, industrialists and professionals showing aspirations to be promoted to the middle class ${ }^{18}$. Another form of clientelism may be found in presidential monarchies such as: Algeria, Tunisia, Egypt or Syria, where a specific form

\footnotetext{
16 Arab Human Development Report 2009..., p. 111.

17 M. Kamrava, Structural impediments to Economic Globalization in the Middle East, „Middle East Policy” 2004, Vol. XI, No. 4, pp. 96-112.

18 For studies of corporatism see also M. Field, The Merchant, The Big Business Families of Saudi Arabia and the Gulf States, Overlook Press 1985.
} 
of partnership can be observed between the ruling and the labour class, incorporated through a variety of union organizations. However, the most significant fact is that the political and economic order in MENA countries, prior to the eruption of the Arab Awakening, was based on an active participation of the urban middle class in maintaining the status quo. Passive compliance with the patron-client system that began in the $1960^{\mathrm{s}}$

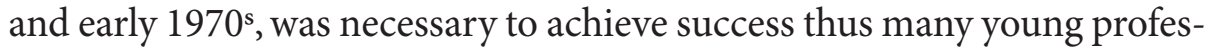
sionals supported it, seeking a rent for their loyalty. Many influential and hermetic groups in Arabic societies such as teachers, bureaucrats, physicians, and managers of the state firms also supported regimes in return for access to social goods and services. This barter, exchange of fair living conditions for unconditional support to undemocratic government one can understand as a "ruling bargain"19. In the late 1970 s drastic shortfalls in oil revenues, mismanagement and corruption began to undermine the patron-client system ${ }^{20}$. At the same time an omnipresent state drifted away from the pool of poorer social clients haunted by unemployment and lack of opportunities. Whilst Arab countries gradually fell into the trap of debt, heavily borrowing internationally and introducing austerity measures, behind the walls of schools and universities the youth began to portray national leaders as the lackeys of the West. Most of the governments, confronted with the crisis of rentierism, drifted in the direction of suppressing the opposition and enhancing autocracy. This state of play changed in the 1990s. At that time, Arab countries were invaded by new ghosts, in particular: declining standards of living, increasing frustration of urban classes in the middle and lower strata, high levels of political repression, and the growing importance of extremist groups and ideologies. In this light "corporatism LTD", as we can name it, was dismantled,

19 D. Brumberg, Authoritarian Legacies and Reform Strategies in the Arab World, (in:) Political Liberalization and Democratization in the Arab World. Volume 1 - Theoretical Perspectives, eds. R. Brynen, B. Korany, P. Noble, Boulder 1995, p. 233.

20 Oil output fell from 31 million barrels per day in 1979 to 18 million in 1982, while the price fell by 50 per cent. The significant shortfall in oil revenues made MENA states addicted to foreign credits and slipped the debts out of their hands. In 1985 MENA countries owed internationally $\$ 80$ billion and $\$ 144$ by the end of 1986 (an increase of 21 per cent in two years). See D. Brumberg, Authoritarian,... op.cit., p. 239. 
and so the whole political system of many North African and Middle East countries. The economy targeted politics with bullet-like issues concerning more jobs, more bread and housing.

Analyzing the Arab uprising in Egypt, Syria, the war against Qaddafi or public unrest in Tunisia, one can draw an analogy between the Arab Spring and acts of disobedience in Muslim societies after Muhammad's revelations. Even in the $8^{\text {th }}$ and $9^{\text {th }}$ centuries there was a strong connection between the ruler and the urban population or, in other words, the palace and the market. The latter became a permanent settlement, towns where merchants and craftsmen, free from the need to grow their own food or tend their own flocks, carried on their specialized activities. The majority of such market towns were smaller than some villages. People visiting markets or permanently living in the cities considered them not only as places of commerce, but also as neutral meeting grounds were information was also the subject of exchange. Between the two poles of the city, the palace and the market, relations were close but complex, based on mutual need. Divergent interests as the ruler needed the economic activities of the city. The urban population, in particular those who possessed wealth and standing, needed the power of the ruler in order to guarantee the supply of food and raw materials from the countryside, guard the traderoutes and conduct relations with other rulers in order to smooth the path of trade ${ }^{21}$. The links of alliance existed there, a patron-client system between craftsmen or merchants treated by the ruler as single groups, liable to pay special dues or provide special services in return for protection of their interests and privileges. Therefore, contemporary corporatism, clientelism, and rentierism in Arab countries are not a novelty. What is more, the current Arab uprising is motivated mainly economically, similarly to social-economic discontent in the early medieval Muslim cities. According to Albert Hourani, in medieval Arab societies sometimes the alliance of interests or a certain balance of power between the ruler and those he relied on, could be shaken. The discontent of possessing classes in the city did not usually take the form of open disobedience because certain privileged groups had too much to lose. However, among the

21 A. Hourani, A History of the Arab Peoples, London 2005, pp. 133-134. 
ordinary people the discontent could take the form of disturbance of order. As Hourani puts it: "The skilled craftsmen and shopkeepers would not easily revolt except under pressure of hardship, the oppression of officials, high process, shortage of food or materials; their normal condition was one of acquiescence, since their interest lay in the preservation of order. The proletariat, however, the mass of rural immigrants, unskilled casual workers, beggars and habitual criminals on the outskirts of the city, was in a more permanent state of unrest"22. A suggestive description by Hourani, compared to current unrest in North Africa and the Middle East, is still relevant. Egypt itself needs to create 700,000 jobs per year just to keep unemployment stable. However, reducing unemployment will require growth rates of around seven percent. Maintaining an old and defunct patron-client system cannot make things better. What is interesting, the Arab Awakening is placed in public squares just as medieval Arab revolts were before in markets. Messages from Tahrir Square read: "Why is Hosni Mubarak 80 years old? Because he doesn't use the national healthcare system." The Arab masses, whether in Tunisia, Egypt or in other Arab countries where this turbulence is likely to unfold, seemingly stems from political suppression, denial of economic activity, abuse of power by authoritarian regimes and the dominance of security establishments. This is indeed a kind of "market democracy" or a revolt against political repression and poor economic conditions.

Amongst the most important factors negatively influencing the Arab countries' prosperity, which have pushed protesters to despair, are state trade policies, etatism and the development of a "semiformal" sector in the Middle Eastern economies. According to the influential "The Economist", in Egypt, where over 40\% of the economy is in state hands: "Private firms are strangled with red tape. Subsidies for food and fuel, worth some $10 \%$ of GDP, are busting the budget. The result is that Egypt faces a fiscal crunch as well as an urgent need to overhaul its economic model"23. In Egypt, the transitional government has expanded subsidies and increased

22 Ibidem, p. 137.

23 Economic reform in the Middle East could prove harder than in Eastern Europe. The West needs to help it along, “The Economist”, 23.06.2011. 
employment in state firms. Economic liberalization has a poor reputation thanks to earlier reforms this decade the fruits of which flowed largely to the well-connected. Therefore, a desire for vengeance against the well-off that helped to bring the crowds onto Tahrir Square, is not astonishing ${ }^{24}$. Subsidies and increased employment in state firms are intertwined with a high degree of both tariff and non-tariff barriers protecting Arab markets against foreign products. According to B. Hoekman and P. Messlin, amongst hurdles to intra-economic cooperation and development of strong Arab corporations, we can include: "business licensing, public sector monopolies, exclusive agency rights, requirements to employ nationals, weak systems of contract enforcement, prohibitions on foreign ownership of real estate, limitations on majority equity to foreigners, corruption and red tape..." 25 . Factors mentioned above resulted in the inability of Middle East and North-African economies to merge into the mainstream of the world economy, which to a large extent is created by giant internationals eliminating small state firms, unable to provide a reasonable scale of production ${ }^{26}$. Moreover, significant state-ownership in MENA is spurring inefficient and protected industries that, further limit the successful adoption of an export strategy.

As the third important impediment to economic development in MENA we can consider the so called "semiformality and parallel economy". M. Kamrava conceptualizes this phenomena as "economic activity of a considerable portion of the economically active population who neither fall inside nor outside of the regulatory purview of state"27. Putting it simply, "semiformality" means that economic activities in the sector straddle institutional formality and informality. As a good example one can consider typical entrepreneurs in the Arab world (i.e. shopkeepers, merchants) who are formally conducting business in accordance with the law (having necessary licenses or permits), but at the same time violating it by not abiding by the law (i.e. not paying taxes or disregarding public

\footnotetext{
24 Ibidem.

25 B. Hoekman and P. Messerlin, Initial Conditions and Incentives for Arab Economic Integration, "Policy Research Working Paper" 2002, No. 2921, p. 13.

26 Ibidem.

27 M. Kamrava, Structural impediments..., pp. 107-108.
} 
obligations). The destructive effect of semiformality on Arab economies and societies is indirect, yet, longstanding and counterproductive. The question is: who loses in this business? The answer is the state. "Informal entrepreneurs" are circumventing the bureaucracy and are conducting their business faster and more effectively in terms of profit, but at the same time labourers are devoid of basic social rights, which leads to multiplying serious social problems: malnutrition, health insecurity, violence and poverty. In situations where the government is only "a plumber" trying to stop leakage of resources, it is difficult to expect development of social policy, which possibly may work as a tranquilizer to a rushed Arab street.

\section{FINAL REMARKS}

Revolutions and uprisings are unpredictable and can have unforeseen consequences. A leading exponent of free market capitalism, Ludwig von Mises, used to say that, considered economically, war and revolution are always bad business ${ }^{28}$. Indeed, according to the "The Economist", in the short term, the economic consequences of the Arab Awakening favour the oil-producing countries that have experienced instability the least, as events in the region have added to the risk premium in the oil price, assisting governments with fiscal expansion to help to head off discontent. Fearing loss of power, in some of the Arab oil empires, governments decided to buy time and "disarm" public anxiety. For example, the King of Saudi Arabia in February 2011 decided to allocate 25.6 bn euro for society. The approach of King Abdullah was also marked by offering the employees an equivalent reaching two-month's remuneration, an allowance equivalent to 375 euro for all unemployed persons, increasing the domestic minimum wage to 560 euro, allocating funds for constructing five hundred thousand flats, granting the health sector about three billion euro, and in addition setting up a committee to fight corruption and giving a guarantee of funds for the recruitment of 60 thousand police offic-

\footnotetext{
28 Spring Tide. Will the Arab risings yield democracy, dictatorship or disorder?, Economist Intelligence Unit, “The Economist” 2011, p. 22.
} 
$\mathrm{ers}^{29}$. A similar action was taken in Jordan. King Abdullah II announced increasing wages for employees in the public sector, military staff, and the creation of twenty one thousand places of employment in the public sector, including six thousand police. What is more, the government announced to introduce subsidies to fuel, food products and an increasing amount of the funds designed to reduce differences between regions of the country ${ }^{30}$. This action will probably be sufficient in the perspective of a few years to impair revolutionary moods of the "Arabic street", however, without structural reforms, the stability in the region will be difficult to achieve. There is a demand for signing a new social contract between the authority and the people, particularly that the contemporary Middle East is "on fire" caused by a population explosion. Two-thirds of the population in Arab countries is less than thirty years old, which constitutes large capital. If appropriately used, perhaps it might play a significant role as a factor in economic growth and stabilization. However, prolonging lack of prospects for young people, resulting from not conducting necessary economic reforms, may perhaps lead to the social exclusion of youth unemployed, and in the end also to the appearance of tensions at any time being very likely to cause more and more serious and de facto uncontrolled outbursts of dissatisfaction. In order to properly use human resources, by 2020 states of the Persian Gulf will have to accept programs enabling them to create about 80 million new jobs ${ }^{31}$.

Notably elsewhere, else in oil-rich Arab countries, unrest has brought serious, short-term economic disruption. In light of economic disturbances in the region one thing is certain - the return of the state. However, the old catch up phrase reminding us that "the state is back" could prove impossible to digest for impoverished Arab societies. A setback for economic liberalization might be caused by associating privatization, liberalization and investment with corporatism, patronage and corruption,

\footnotetext{
29 A. Hanieh, Rewolucja w Egipcie to nie tylko kwestia „zmiany”, "Le Monde Diplomatique" 2011, No. 4 (62), p. 29.

30 Ibidem.

31 N. Dhillon, Middle East Youth Bulge: Challenge or Opportunity? www.brookings. edu/speeches/2008/0522_middle_east_youth_dhillon.aspx, 22.05.2008. [15.01.2012].
} 
accompanied with the political elite's drive to strain the ambition of the unemployed and imprisoning within the feeling of state powered déjà $v u$. Therefore, the internal consequences of the Arab Awakening may be of a grievous nature for the poorest. Even now, in some of the MENA countries, trade and industry in 2011 and 2012 will probably suffer signs of a serious slowdown. Along with the shallow tourism benefits, economies of the Arab countries may face stagnation. Adding to this the high cost of disruptions, strikes, civil wars, the exodus of foreign workers and the flight of inward investments, economic hardship may prove to be unbearable even for idealists and the supporters of democracy.

The current turn of Arab uprisings has proved the importance of both external and internal economic and social factors. One should not forget that the Arab people demonstrated above all against high food prices, high unemployment and corruption, which in turn, impede economic development. Once again it is crucial to reflect on the continuous rise and persistence of unemployment, particularly among the youth, in the context of demographic transition and a huge increase in the working-age population, which are the key challenges facing Arab countries.

The rising tide of unemployment (the highest in the world among women) and its long term nature have created a sense of frustration and discontent. Linked to this, is the inadequate protection of human rights, in particular the right to freedom of speech and assembly, the right to organize and to collective bargaining, leaving both the employed and unemployed without sufficient legal protection, thus highlighting the restrictions of democratic space. Unemployment and poverty goes along with the phenomenon of informality which manifests the vicious circle of poverty and weak social, economic and political rights. The vast majority of the poor in the Arab states live in the informal sector with limited secured access to land and other resources. They run unregistered businesses, and often occupy land to which they have no formal rights. The very legitimacy of the state is undermined by these millions of people who are excluded from legal protection, legal identity and channels of representation. Hence the relationship between informality, poverty, economic, legal, social and political exclusion uncovers the exclusionary dynamics of the power and wealth base. 
Out of control privatization, often 19-th century inhuman handling of workers, widespread corruption, and lack of transparency and accountability have caused the income gap between the rich and poor in each state to widen tremendously, particularly in the poor ones that represent about $90 \%$ of the Arab population. Political and economic corruption has enabled the rich and powerful few to own and control most of the wealth in society, reducing the living standards of the poor to near subsistence, thus causing poverty and hopelessness to spread and deepen its roots. In fact, developments associated with privatization and free market philosophy have caused wealth and income to be transferred from the poor to the rich via government policies, political corruption, and monopoly practices and, in the case of some states, through higher taxes and fees imposed on all types of public services. Thus, while the richest $10 \%$ of the Arab population are secure for at least the medium term, the poor $90 \%$ continues to suffer economic and social insecurity and human degradation.

Undoubtedly the lack of economic reform may lead to even more radical changes, comparable to those that have swept through the region, particularly in Egypt, where there is already talk of the need for a "second revolution" to address economic issues ${ }^{32}$. New governments in Egypt and Tunisia will have to resolve the problems with bread and fuel subsidies to the poor, and at the same time to try to keep foreign capital from panicking and "flying away" into more stabilized markets. A ray of hope may be directed from rich countries, which have committed substantial financial resources to support pro-democratic movements in North Africa, especially that at the end of May 2011, the G8 pledged loans and grants totaling $\$ 40$ billion $^{33}$. Yet, even with this economic help, the question remains

32 J. Sfakianakis, The Arab spring risks economic malaise, FT. com, April 5, 2011. available on http://www.ft.com/cms/s/0/83410a60-5fb7-11e0-a718-00144feab49a. html\#axzz1QUPhGth5 [15.01.2012].

33 This includes over $\$ 10$ billion in direct aid to Tunisia and Egypt, a figure that will be matched by Gulf states such as Saudi Arabia, Kuwait and Qatar. Bloomberg, G- 8 Finds $\$ 40$ Bln for Arab Spring From Development Banks, Aid, Bloomberg Businessweek website, May 27 $7^{\text {th }} 2011$, http://www.businessweek.com/news/2011-05-27/g-8- finds-40-bln-forarab-spring-from-development-banks-aid.html [15.01.2012]. 
whether Arab countries will speed up towards full democratization in politics, very often standing in contrast with their cultures, traditions, history, ideas and beliefs. Although the World Bank or G-8 are certain of this trajectory, meaning inviting the Arab countries to immediate transformation, doubts arise when we compare contemporary, dying away economic power of the West with the undemocratic but economically exploding Chinese tiger. Maybe the slogan "economy stupid!" should be matched with the gradual regime changes towards more transparency and openness in the MENA region. There is no easy way to clear a path to economic reform in North Africa and the Middle East. Democracy is a western point of view, good economics - much more universaly necessary. 